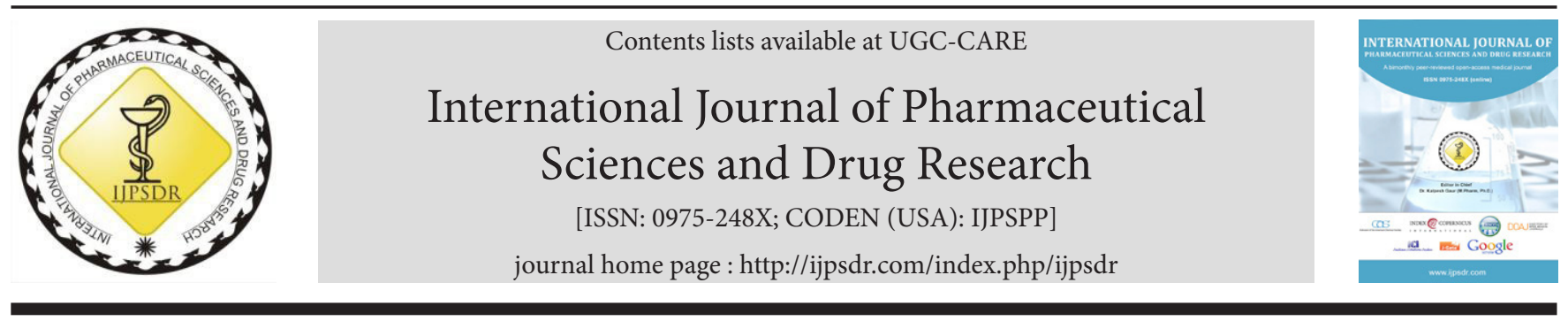

Research Article

\title{
Stability-indicating Reversed Phase-Ultra Performance Liquid Chromatography Method Development and Validation for Simultaneous Determination of Encorafenib and Binimetinib in Formulation
}

\author{
Taduvai Venkata Raveendranath ${ }^{1 *}$, Rajaiah Thangaraj Saravanakumar $^{1}$, Anjana Male $^{2}$ \\ ${ }^{1}$ Department of Pharmacy, Annamalai University, Annamalai Nagar, Chidambaram-608002, Tamil Nadu, India \\ ${ }^{2}$ Department of Pharmaceutical Chemistry and Phytochemistry, Nirmala College of Pharmacy, Guntur-522503, Andhra Pradesh, India
}

\author{
A R T I C L E I N F O \\ Article history: \\ Received: 03 May, 2020 \\ Revised: 12 August, 2020 \\ Accepted: 25 August, 2020 \\ Published: 30 September, 2020 \\ Keywords: \\ Binimetinib, \\ Encorafenib, \\ Stability studies, \\ Ultra performance liquid \\ chromatography (UPLC), \\ Validation. \\ DOI: \\ 10.25004/IJPSDR.2020.120509
}

\begin{abstract}
A B S T R A C T
Simple, accurate, and the precise stability-indicating method was developed for the simultaneous estimation of the encorafenib (ECRB) and binimetinib (BMTB) in a dosage form by ultra performance liquid chromatography (UPLC). Chromatographic elution was processed through an HSS C18 $(100 \times 2.1 \mathrm{~mm}, 1.8 \mathrm{~m})$ reverse phase column, and the mobile phase composition of $0.01 \mathrm{~N} \mathrm{KH}_{2} \mathrm{PO}_{4}$ buffer $(\mathrm{pH} 3.5)$ and acetonitrile in the proportion of 55:45 was processed through a column at a flow rate of $1 \mathrm{~mL} / \mathrm{min}$. The temperature of the column oven was kept at $30^{\circ} \mathrm{C}$, and the wavelength maximum of detection system was set to $294 \mathrm{~nm}$. Retention times of ECRB and BMTB were found to be 0.767 and 1.13 minutes, respectively. Repeatability of the method was determined in the form of $\%$ relative standard deviation (RSD), and findings were 0.3 and 0.6 for ECRB and BMTB, respectively. The percentage recovery of the method was found to be 99.59 and $99.7 \%$ for ECRB and BMTB, respectively. The limit of detection (LOD) and the limit of quantification (LOQ) values obtained from regression equations of ECRB and BMTB were $0.51,1.55 \mathrm{mg} / \mathrm{mL}$ and $1.47,4.44 \mathrm{mg} / \mathrm{mL}$, respectively. The regression equation of ECRB was $y=6,684 x+18,102$, and BMTB was $y=13,118 x+2,159$. Two analytes were subjected to acid, peroxide, photolytic, alkali, neutral, and thermal degradation studies, and the results shown that the percentage of degradation was found between 0.76 and $6.88 \%$. Retention times and the total run time of two drugs were decreased, and the developed method was simple and economical. So, the developed method can be adopted in industries as a regular quality control test for the quantification of ECRB and BMTB.
\end{abstract}

\section{INTRODUCTION}

The ECRB is a drug component available in the market as Braftovi, utilized in the treatment of different melanomas. It belongs to a BRAF inhibitor that affects the key enzymes involved in the mitogen-activated protein kinase (MAPK) signaling path. This path of signaling takes place in many kinds of cancers, together with colorectal cancer and melanomas ${ }^{[1,2]}$ ECRB inhibits the ATP-competitive RAF kinase, downregulates cyclin-D1, and decreases ERK phosphorylation. ${ }^{[3-5]}$ This stops the cell cycling process in phase-G1, prompting senescence without apoptosis. ECRB chemically designated as methyl[ $(2 S)-1-\{[4-(3-\{5$-chloro2-fluoro-3-[(methylsulfonyl) amino] phenyl\}-1-isopropyl-
1H-pyrazol-4-yl)-2-pyrimidinyl] amino\}-2-propanyl] carbamate ${ }^{[1,3]}$ with molecular weight and formula of $540.011 \mathrm{~g} /$ mole and $\mathrm{C}_{22} \mathrm{H}_{27} \mathrm{ClFN}_{7} \mathrm{O}_{4} \mathrm{~S}$, respectively (Fig. 1).

BMTB (trade name Mektovi) selectively inhibits MEK, a central kinase in the tumor stimulating MAPK-path. Incongruous stimulation of the path has been shown to ensue in several cancers. ${ }^{[6]}$ BMTB is a mitogen-activated protein kinase (MEK) inhibitor available orally, or, more specifically, an inhibitor of MAP2K. ${ }^{[7]}$ MEK is part of the rat sarcoma (RAS) pathway, which is involved in cell proliferation and survival. MEK is upregulated in many forms of cancer. ${ }^{[8]}$ BMTB, uncompetitive with ATP, binds to and inhibits the activity of MEK1/2 kinase, which has been

\footnotetext{
*Corresponding Author: Taduvai Venkata Raveendranath

Address: Research Scholar, Department of Pharmacy, Annamalai University, Chidambaram-608002, Tamilnadu, India

Email $\bowtie:$ ravi.6030@gmail.com

Tel.: +91-9491338230

Relevant conflicts of interest/financial disclosures: The authors declare that the research was conducted in the absence of any commercial or financial relationships that could be construed as a potential conflict of interest.

Copyright (c) 2020 Taduvai Venkata Raveendranath et al. This is an open access article distributed under the terms of the Creative Commons Attribution- NonCommercial-ShareAlike 4.0 International License which allows others to remix, tweak, and build upon the work non-commercially, as long as the author is credited and the new creations are licensed under the identical terms.
} 
shown to regulate several key cellular activities, including proliferation, survival, and angiogenesis. BMTB chemically designated as 5-((4-bromo-2-fluorophenyl) amino)-4-fluoroN-(2-hydroxyethoxy)-1-methyl-1H-benzo[d] imidazole6-carboxamide ${ }^{[6-8]}$ with molecular weight and formula of $441.23 \mathrm{~g} /$ mole and $\mathrm{C}_{17} \mathrm{H}_{15} \mathrm{BrF}_{2} \mathrm{~N}_{4} \mathrm{O}_{3}$, respectively (Fig. 1).

ECRB and BMTB target two dissimilar kinases in the path of RAS-RAF-MEK-ERK. A combination of ECRB and BMTB results in superior anti-proliferating action in vitro in BRAF mutation-positive cell lines, compared with activity of any single drug alone. ${ }^{[7]}$ In addition to the above, these two drug combinations acted to defer the emergence of resistance in BRAF-V600E mutant human melanoma xenografts in mice compared with the administration of any one drug alone. ${ }^{[4,8]}$

The literature review unveils that very less UPLC-MS/ $\mathrm{MS}^{[9]}$ and reverse-phase high performance liquid chromatographic (RP-HPLC) ${ }^{[10]}$ techniques have been established for the determination of ECRB and BMTB. Based on the reported HPLC methods, there is a need to develop a stability-indicating RP-UPLC method for the simultaneous estimation of ECRB and BMTB in bulk and dosage form.

\section{Materials AND METhods}

\section{Chemicals and Reagents}

The active pharmaceutical ingredient (API) of ECRB and BMTB were obtained from Spectrum Pharma Research Solutions, Hyderabad. HPLC-grade methanol and acetonitrile were procured from Merck Chemical Division, Mumbai, India. Potassium dihydrogen orthophosphate, orthophosphoric acid, sodium dihydrogen orthophosphate, and HPLC-grade water were bought from Rankem, Avantor Performance Material India Limited. Braftovi capsules and Mektovi tablets were obtained from a local pharmacy.

\section{Chromatographic System}

Liquid chromatographic UPLC system of Waters equipped with photodiode array detector (PDA), auto-sampling unit, and HSS C18 $(100 \times 2.1 \mathrm{~mm}, 1.8 \mathrm{~m})$ reverse phase column. The mobile phase combination of $0.01 \mathrm{~N} \mathrm{KH}_{2} \mathrm{PO}_{4}$ buffer ( $\mathrm{pH}$ 3.5) and acetonitrile in the ratio of 55:45 was pumped through a column at a flow rate of $1 \mathrm{~mL} / \mathrm{min}$. The column oven temperature was maintained at $30^{\circ} \mathrm{C}$, and the detection wavelength was processed at $294 \mathrm{~nm}$. The
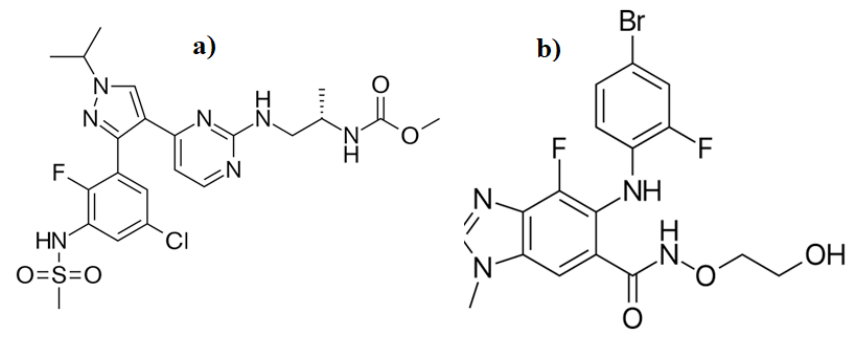

Fig. 1: Chemical structures of a) ECRB; b) BMTB integration of output signals was monitored and processed by waters Empower software-2.0.

\section{Diluents}

Depending upon the solubility of the drugs, diluent was optimized. Initially dissolved in methanol and diluted with acetonitrile and water (50:50).

\section{Preparation of Standard Stock Solutions}

Exactly weighed $90 \mathrm{mg}$ of ECRB and $9 \mathrm{mg}$ of BMTB poured into two $50 \mathrm{~mL}$ volumetric flasks alone. $10 \mathrm{~mL}$ of diluent was added and vortexed for 10 minutes. Flasks were made up of diluent and marked as standard stock solutions 1 and $2(1,800 \mu \mathrm{g} / \mathrm{mL}$ of ECRB and $180 \mu \mathrm{g} / \mathrm{mL}$ BMTB). From each stock solution, $1 \mathrm{~mL}$ was pipetted out and poured into a $10 \mathrm{~mL}$ volumetric flask, and the final volume was made up to mark with diluent to get $180 \mu \mathrm{g} / \mathrm{mL}$ of ECRB and $18 \mu \mathrm{g} / \mathrm{mL}$ of BMTB.

\section{Preparation of Sample Stock Solutions}

5 tablets were weighed, and the average weight of each tablet was calculated. The weight equivalent to one tablet was transferred into a $500 \mathrm{~mL}$ volumetric flask, and $25 \mathrm{~mL}$ of diluent was added and sonicated for 25 minutes. Further, the volume was made up with diluent and filtered through a $0.45 \mu$ filter $(900 \mu \mathrm{g} / \mathrm{mL}$ of ECRB and $90 \mu \mathrm{g} / \mathrm{mL}$ of BMTB). $2 \mathrm{~mL}$ of the resultant solution was poured into a $10 \mathrm{~mL}$ volumetric flask and made up with diluent $(180 \mu \mathrm{g} / \mathrm{mL}$ of ECRB and $18 \mu \mathrm{g} / \mathrm{mL}$ of BMTB).

\section{Preparation of Buffer}

Accurately weighed $1.36 \mathrm{gm}$ of potassium dihydrogen orthophosphate in a $1,000 \mathrm{~mL}$ of volumetric flask and added about $800 \mathrm{~mL}$ of milli-Q water. The resulting solution was subjected to sonication for 10 minutes, make up the volume with water, and then adjust the $\mathrm{pH}$ to 3.5 with $0.1 \%$ orthophosphoric acid solution.

\section{Method Validation}

The developed method for ECRB and BMTB was subjected to validation for the parameters, like system suitability, robustness, linearity, LOD, precision, LOQ, and accuracy as per the ICH guidelines. ${ }^{[11-15]}$

\section{RESULTS}

\section{Method Development and Optimization}

We tried different mobile phase combinations with methanol, water, acetonitrile, and buffer. At all the combinations, the resulting chromatograms got a poor resolution, theoretical plates, and peak shape. ${ }^{[15-17]}$ Finally, excellent chromatographic efficiency parameters were obtained with the mobile phase composition of $0.01 \mathrm{~N}$ $\mathrm{KH}_{2} \mathrm{PO}_{4}$ buffer ( $\mathrm{pH} 3.5$ ), and acetonitrile in the ratio of 55:45 \%v/v pumped through an HSS C18 (100 × $2.1 \mathrm{~mm}$, $1.8 \mathrm{~m}$ ) reverse phase column, at a flow rate of $1 \mathrm{~mL} / \mathrm{min}$. The 
column oven temperature was maintained at $30^{\circ} \mathrm{C}$, and the detection wavelength was processed at $294 \mathrm{~nm}$. Based on the solubility, all the dilutions were made with acetonitrile and water in the ratio of 50:50 \%v/v. Retention times of ECRB and BMTB were found to be 0.767 and 1.13 minutes, respectively. An injection volume of $0.3 \mathrm{~mL}$ was infused through a UPLC system to get better performance.

\section{System Suitability}

The system suitability variables were estimated by processing standard ECRB and BMTB solutions, and the same was injected six times into a chromatographic system. The variables, like resolution, United States Pharmacopoeia (USP) plate count, and peak tailing, were estimated ${ }^{[18]}$ The findings were represented in Table 1 and Fig. 2.

\section{Specificity}

Method specificity was determined by infusing the blank, placebo, standard, and sample solutions into a chromatographic system, and the resulting chromatograms were evaluated for interference with the excipients, degradants, and other components that may be expected to be present. ${ }^{[13]}$ Blank, standard, formulation, and placebo chromatograms were represented in Fig. 3.

\section{Precision}

The precision of the present work was assessed in terms of method and intermediate precision. The method precision (repeatability) was estimated by infusing six standard solutions and six sample solutions. Intermediate precision was evaluated by infusing six standard solutions and six sample solutions on different days by different employees on different chromatographic systems. ${ }^{[14,16]}$

The peak responses of all the chromatograms were taken, and standard deviation, \% RSD, and percentage assay of sample solutions were calculated. The findings were shown in Tables 2 and 3.

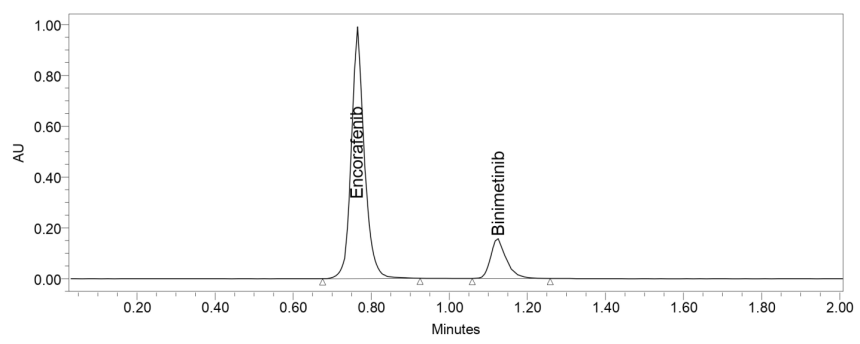

Fig. 2: System suitability chromatogram of ECRB and BMTB

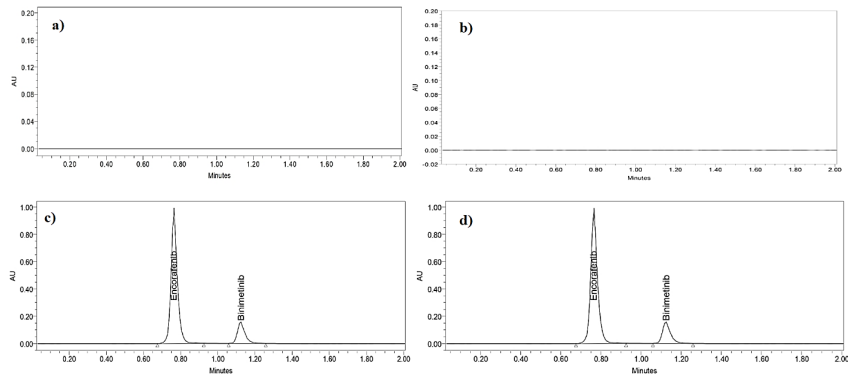

Fig. 3: Chromatograms of a) Blank; b) Placebo; c) Standard; d) Sample

Table 1: System suitability parameters for ECRB and BMTB

\begin{tabular}{|c|c|c|c|}
\hline \multirow[b]{2}{*}{ S. No. } & \multicolumn{3}{|l|}{$E C R B$} \\
\hline & $R T$ (min) & USP plate count & Tailing \\
\hline 1 & 0.766 & 2,732 & 1.22 \\
\hline 2 & 0.766 & 2,641 & 1.27 \\
\hline 3 & 0.766 & 2,624 & 1.26 \\
\hline 4 & 0.767 & 2,625 & 1.27 \\
\hline 5 & 0.767 & 2,686 & 1.24 \\
\hline 6 & 0.767 & 2,599 & 1.27 \\
\hline \multicolumn{4}{|c|}{ Table 2: Repeatability results of ECRB and BMTB } \\
\hline S. No. & \multicolumn{2}{|c|}{ Area of ECRB } & Area of BMTB \\
\hline 1. & \multicolumn{2}{|l|}{$1,246,477$} & 243,254 \\
\hline 2. & \multicolumn{2}{|l|}{$1,252,281$} & 243,393 \\
\hline 3. & $1,251,131$ & & 242,062 \\
\hline 4. & \multicolumn{2}{|l|}{$1,248,204$} & 245,139 \\
\hline 5. & \multicolumn{2}{|l|}{$1,242,873$} & 242,591 \\
\hline 6. & \multicolumn{2}{|l|}{$1,252,694$} & 245,621 \\
\hline Mean & \multicolumn{2}{|l|}{$1,248,943$} & 243,677 \\
\hline SD & \multicolumn{2}{|l|}{$3,833.3$} & $1,411.7$ \\
\hline \% RSD & 0.3 & & 0.6 \\
\hline
\end{tabular}

SD: Standard deviation; RSD: Relative standard deviation $B M T B$

$\begin{array}{llll}R T \text { (min) } & \text { USP plate count } & \text { Tailing } & \text { USP resolution } \\ 1.128 & 3,728 & 1.16 & 5.2 \\ 1.128 & 3,585 & 1.19 & 5 \\ 1.129 & 3,583 & 1.19 & 5 \\ 1.13 & 3,625 & 1.18 & 5 \\ 1.13 & 3,548 & 1.18 & 4.9 \\ 1.13 & 3,453 & 1.19 & 4.8\end{array}$

Table 3: Intermediate precision results of ECRB and BMTB

\begin{tabular}{lll}
\hline S. No. & Area of ECRB & Area of BMTB \\
\hline 1. & $1,246,469$ & 243,850 \\
2. & $1,244,094$ & 242,664 \\
3. & $1,243,469$ & 245,656 \\
4. & $1,237,521$ & 242,089 \\
5. & $1,233,073$ & 245,904 \\
6. & $1,236,125$ & 243,739 \\
Mean & $1,240,125$ & 243,984 \\
SD & $5,285.7$ & $1,542.3$ \\
$\%$ RSD & 0.4 & 0.6 \\
\hline
\end{tabular}

SD: Standard deviation; RSD: Relative standard deviation 
Development of Encorafenib and Binimetinib in Formulation by RP-UPLC Method

Table 4: Accuracy results of ECRB and BMTB

\begin{tabular}{|c|c|c|c|c|c|c|c|c|}
\hline$\%$ level & $\begin{array}{l}\text { Amount } \\
\text { spiked } \\
(\mu \mathrm{g} / \mathrm{mL})\end{array}$ & $\begin{array}{l}\text { Amount } \\
\text { recovered } \\
(\mu \mathrm{g} / \mathrm{mL})\end{array}$ & $\%$ recovery & Mean \% recovery & $\begin{array}{l}\text { Amount } \\
\text { spiked } \\
(\mu \mathrm{g} / \mathrm{mL})\end{array}$ & $\begin{array}{l}\text { Amount } \\
\text { recovered } \\
(\mu \mathrm{g} / \mathrm{mL})\end{array}$ & $\begin{array}{l}\% \\
\text { recovery }\end{array}$ & $\begin{array}{l}\text { Mean \% } \\
\text { recovery }\end{array}$ \\
\hline \multirow{3}{*}{50} & 90 & 89.72457 & 99.69 & \multirow{9}{*}{99.59} & 9 & 8.990776 & 99.9 & \multirow{9}{*}{99.7} \\
\hline & 90 & 89.71574 & 99.68 & & 9 & 8.988794 & 99.88 & \\
\hline & 90 & 89.68253 & 99.65 & & 9 & 8.993215 & 99.92 & \\
\hline \multirow{3}{*}{100} & 180 & 179.4969 & 99.72 & & 18 & 17.8281 & 99.04 & \\
\hline & 180 & 179.2611 & 99.59 & & 18 & 17.91439 & 99.52 & \\
\hline & 100 & 99.08887 & 99.09 & & 18 & 17.93818 & 99.66 & \\
\hline \multirow{3}{*}{150} & 270 & 269.1872 & 99.7 & & 27 & 26.95213 & 99.82 & \\
\hline & 270 & 268.6239 & 99.49 & & 27 & 26.97965 & 99.92 & \\
\hline & 270 & 269.2932 & 99.74 & & 27 & 26.88817 & 99.59 & \\
\hline
\end{tabular}

\begin{tabular}{llll}
\hline \multicolumn{4}{c}{ Table 5: Linearity results for ECRB and BMTB } \\
\hline ECRB & \multicolumn{3}{l}{ BMTB } \\
\hline Conc. $(\mu \mathrm{g} / \mathrm{mL})$ & Peak area & Conc. $(\mu \mathrm{g} / \mathrm{mL})$ & Peak area \\
\hline 0 & 0 & 0 & 0 \\
45 & 322,448 & 4.5 & 60,978 \\
90 & 633,298 & 9 & 123,832 \\
135 & 934,969 & 13.5 & 179,592 \\
180 & $1,211,063$ & 18 & 235,754 \\
225 & $1,536,452$ & 22.5 & 300,887 \\
270 & $1,805,748$ & 27 & 353,700 \\
\hline
\end{tabular}

Table 6: LOD and LOQ results for ECRB and BMTB

\begin{tabular}{lll}
\hline Analyte & $L O D(\mu \mathrm{g} / \mathrm{mL})$ & $L O Q(\mu \mathrm{g} / \mathrm{mL})$ \\
\hline ECRB & 0.51 & 1.55 \\
BMTB & 1.47 & 4.44 \\
\hline
\end{tabular}

\section{Accuracy}

Method accuracy was estimated at three variable concentrations of 50,100 , and $150 \%$ levels by spiking the known amount of the drug analytes. ${ }^{[17]}$ The \% recovery at each level was calculated, and the findings were represented in Table 4.

\section{Linearity}

The linearity of the developed method was evaluated by processing six different concentration levels of both ECRB and BMTB over the concentration of 45 to $270 \mu \mathrm{g} / \mathrm{mL}$ and 4.5 to $27 \mu \mathrm{g} / \mathrm{mL}$. Each concentration level was processed in triplicates. ${ }^{[11,16]}$ The linearity plots were acquired by plotting peak response (on X-axis) vs. concentration (on Y-axis). The results of the linearity were represented in Table 5, and Figs 4 and 5.

\section{Limit of Detection (LOD) and Limit of Quantification (LOQ)}

The LOD is the lowest quantity of drugs in a sample that can be identified but cannot be quantified exactly. LOQ is the lowest quantity of a drug in an analyte, which can be quantitatively estimated with suitable accuracy and

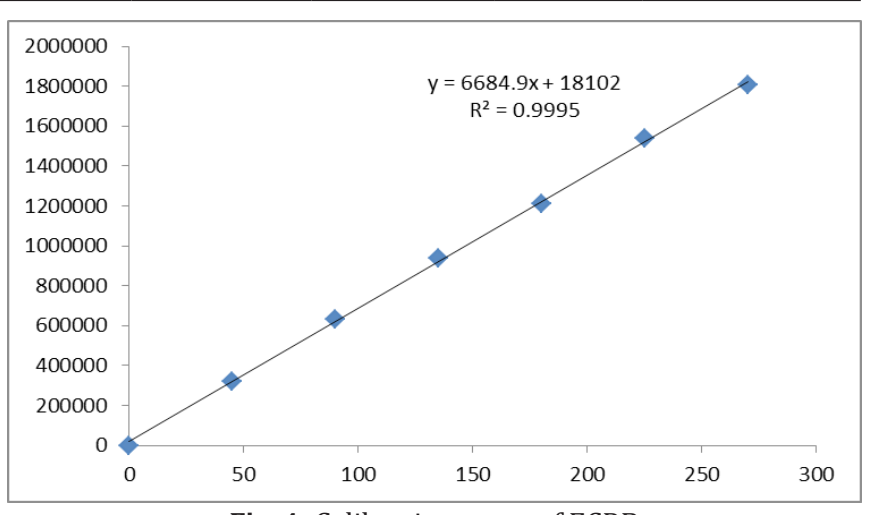

Fig. 4: Calibration curve of ECRB

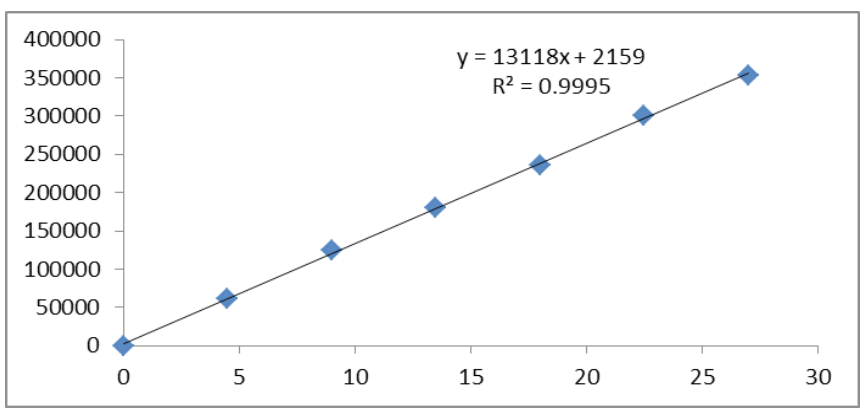

Fig. 5: Calibration curve of BMTB

precision. The LOD and LOQ values were calculated from the linearity data by utilizing the standard deviation and slope of the curve. ${ }^{[11,14]}$ The resulting LOD and LOQ findings were represented in Table 6.

\section{Robustness}

The method robustness was processed by introducing small variation in the optimized liquid chromatography (LC) conditions, such as, organic phase in the mobile phase $( \pm 5 \%)$, flow rate $(-0.27$ and $+0.33 \mathrm{~mL} / \mathrm{min})$, and column temperature $\left( \pm 5^{\circ} \mathrm{C}\right)$. The findings were shown in Table 7 .

\section{Degradation Studies}

Alkali Degradation Studies

To $1 \mathrm{~mL}$ of each ECRB and BMTB stock solution, $1 \mathrm{~mL}$ of $2 \mathrm{~N} \mathrm{NaOH}$ was added to a $10 \mathrm{~mL}$ volumetric flask and 
kept at $60^{\circ} \mathrm{C}$ for 30 minutes. Further, the resulting solution was made up to the mark to get 180 and $18 \mu \mathrm{g} / \mathrm{mL}$ concentrations of ECRB and BMTB, respectively. From that, $0.3 \mu \mathrm{L}$ of the solution was infused into a UPLC system, and the resultant chromatograms were analyzed for the stability of analytes. ${ }^{[12]}$ The findings were represented in Table 8 and Fig. 6.

\section{Photolytic Stability Study}

For the photolytic stability study, ECRB 1,800 $\mu \mathrm{g} / \mathrm{mL}$ and BMTB $180 \mu \mathrm{g} / \mathrm{mL}$ solutions were exposed to UV-light by placing the solutions in UV cabinet for 1-day or 200 Watthours $/ \mathrm{m}^{2}$ in a photostability chamber. The resulting solutions were combined in a $10 \mathrm{~mL}$ volumetric flask and made up to the mark with diluent to get 180 and $18 \mu \mathrm{g} / \mathrm{mL}$ concentrations of ECRB and BMTB, respectively. From that, $0.3 \mu \mathrm{L}$ of the solution was infused into a UPLC system, and the resultant chromatograms were analyzed for analytes' stability. The findings were represented in Table 8 and Fig. 6.

\section{Acid Degradation Studies}

To $1 \mathrm{~mL}$ of each ECRB and BMTB stock solution, $0.01 \mathrm{~mL}$ of $2 \mathrm{~N}$ hydrochloric acid was added to a $10 \mathrm{~mL}$ volumetric flask and refluxed at $60^{\circ} \mathrm{C}$ for 30 minutes. Further, the resulting solution was made up to the mark to get 180 and $18 \mu \mathrm{g} / \mathrm{mL}$ concentrations of ECRB and BMTB, respectively. From that, $0.3 \mu \mathrm{L}$ of the solution was infused into a UPLC system, and the resultant chromatograms were analyzed for the stability of analytes. The findings were represented in Table 8 and Fig. 6.

\section{Neutral Degradation Studies}

To $1 \mathrm{~mL}$ of each ECRB and BMTB stock solution, $5 \mathrm{~mL}$ of water was added into a $10 \mathrm{~mL}$ volumetric flask and kept

Table 7: Robustness data for ECRB and BMTB

\begin{tabular}{llll}
\hline S. No. & Variation in LC conditions & ECRB \% RSD & BMTB \% RSD \\
\hline 1 & Flow rate (-) $0.27 \mathrm{~mL} / \mathrm{min}$ & 0.8 & 0.7 \\
2 & Flow rate $(+) 0.33 \mathrm{~mL} / \mathrm{min}$ & 0.5 & 0.5 \\
3 & Organic phase $-5 \%$ & 0.6 & 0.3 \\
4 & Organic phase $+5 \%$ & 0.6 & 0.6 \\
5 & Temperature at $25^{\circ} \mathrm{C}$ & 1.1 & 0.9 \\
6 & Temperature at $35^{\circ} \mathrm{C}$ & 1 & 0.8 \\
\hline
\end{tabular}

for refluxing at $60^{\circ} \mathrm{C}$ for 1 -hour. Further, the resulting solution was made up to the mark to get 180 and $18 \mu \mathrm{g} / \mathrm{mL}$ concentrations of ECRB and BMTB, respectively. From that, $0.3 \mu \mathrm{L}$ of the solution was infused into a UPLC system, and the resultant chromatograms were analyzed for the stability of analytes. The findings were represented in Table 8 and Fig. 6.

\section{Oxidation}

To $1 \mathrm{~mL}$ of each ECRB and BMTB stock solution, $1 \mathrm{~mL}$ of $20 \%$ hydrogen peroxide $\left(\mathrm{H}_{2} \mathrm{O}_{2}\right)$ was added into a $10 \mathrm{~mL}$ volumetric flask and keptat $60^{\circ} \mathrm{C}$ for 30 minutes. Further, the resulting solution was made up to the mark to get 180 and $18 \mu \mathrm{g} / \mathrm{mL}$ concentrations of ECRB and BMTB, respectively. From that, $0.3 \mu \mathrm{L}$ of the solution was infused into a UPLC system, and the resultant chromatograms were analyzed for the stability of analytes. The findings were represented in Table 8 and Fig. 6.

\section{Dry Heat Degradation Studies}

To a $10 \mathrm{~mL}$ volumetric flask, add $1 \mathrm{~mL}$ each ECRB and BMTB stock solution and monitor at $105^{\circ} \mathrm{C}$ for 1 -hour in a hot air oven to perform the dry heat stability study. Further, the resulting solution was made up to the mark to get 180 and $18 \mu \mathrm{g} / \mathrm{mL}$ concentrations of ECRB and BMTB,
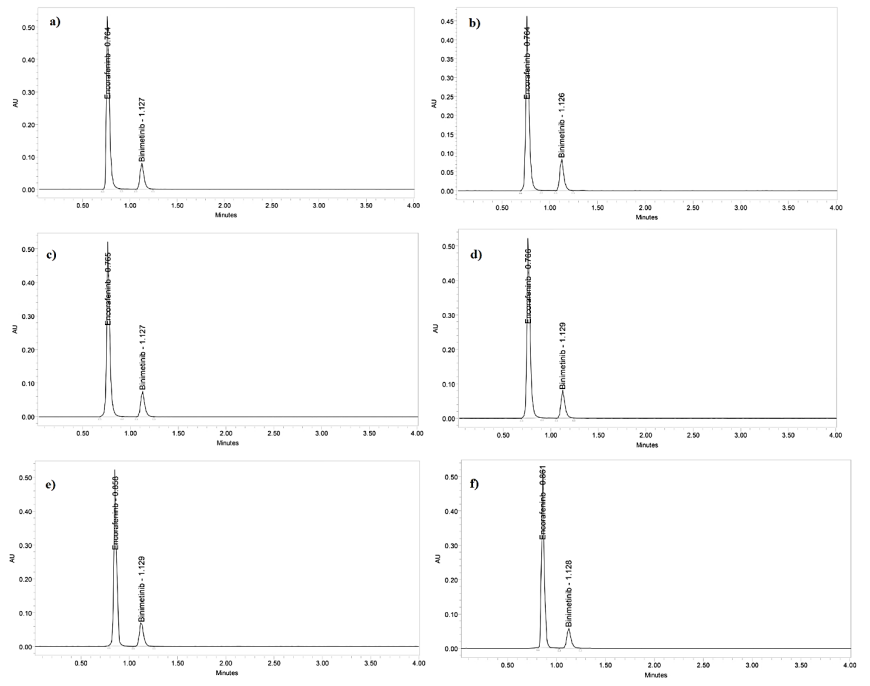

Fig. 6: Representative chromatograms of a) UV-degradation; b) Peroxide degradation; c) Thermal degradation; d) Neutral degradation; e) Acid degradation; f) Alkali degradation

Table 8: Degradation data of ECRB and BMTB

\begin{tabular}{lllllll}
\hline & \multicolumn{1}{l}{ ECRB } & \multicolumn{3}{c}{ BMTB } \\
\cline { 2 - 7 } Type of degradation & Area & \% recovered & \% degraded & Area & \% recovered & \% degraded \\
\hline Acid & $1,211,851$ & 97.47 & 2.53 & 237,330 & 97.34 & 2.66 \\
Alkali & $1,202,123$ & 96.69 & 3.31 & 236,412 & 96.97 & 3.03 \\
Peroxide & $1,157,758$ & 93.12 & 6.88 & 231,328 & 94.88 & 5.12 \\
Thermal & $1,218,460$ & 98 & 2 & 236,704 & 97.08 & 2.92 \\
UV light & $1,208,181$ & 97.18 & 2.82 & 239,749 & 98.33 & 1.67 \\
Neutral & $1,225,794$ & 98.59 & 1.41 & 241,947 & 99.24 & 0.76 \\
\hline
\end{tabular}


respectively. From that, $0.3 \mu \mathrm{L}$ of the solution was infused into a UPLC system, and the resultant chromatograms were analyzed for the stability of analytes. The findings were represented in Table 8 and Fig. 6.

\section{DISCUSSION}

After the method development trials, chromatographic parameters were optimized with mobile phase composition of $0.01 \mathrm{~N} \mathrm{KH}_{2} \mathrm{PO}_{4}$ buffer ( $\mathrm{pH} 3.5$ ) and acetonitrile in the ratio of $55: 45 \% \mathrm{v} / \mathrm{v}$, HSS C18 $(100 \times 2.1 \mathrm{~mm}, 1.8 \mathrm{~m})$ reverse phase column, a flow rate of $1 \mathrm{~mL} / \mathrm{min}$, column temperature of $30^{\circ} \mathrm{C}$ and the detection wavelength at $294 \mathrm{~nm}$. The optimized method was processed for validation as per the guidelines of ICH. In the system suitability studies, the tailing factor should be $<2$, the resolution must be $>2$, and plate count should be $>2,000$. All the suitable system parameters were passed and were within limits. Retention times of ECRB and BMTB were 0.767, 1.13, and 3.648 minutes, in that order. We did not find any additional peaks in blank and placebo at these drugs' retention times in this technique. So this technique was said to be specific.

The average area, standard deviation (SD), and $\%$ RSD were calculated for the method and intermediate precision, and the \% RSD values were less than $0.6 \%$ for ECRB and BMTB. As the limit of precision was $<2$ and both the precisions were passed in this analysis process. The method has a high degree of accuracy based on the mean recovery values and was 99.59 and $99.7 \%$ for ECRB and BMTB, respectively. The correlation coefficient values obtained for both the drugs were $>0.999$, and it proves that the method has a high degree of linearity. The method robustness was processed by variation in the mobile phase, flow rate, column temperature, and $\%$ RSD was calculated. The resultant findings (Table 7) prove the method robustness. Further, two analytes were subjected to acid, peroxide, photolytic, alkali, neutral, and thermal degradation studies, and the results shown that the drugs were prone to degradation between 0.76 and $6.88 \%$.

\section{CONCLUSION}

A simple, accurate, and precise method was developed for the simultaneous estimation of the ECRB and BMTB in tablet dosage form by the RP-UPLC technique. Retention times of ECRB and BMTB were found to be 0.767 and 1.13 minutes, respectively. Chromatographic elution was processed through an HSS C18 (100 × $2.1 \mathrm{~mm}, 1.8 \mathrm{~m})$ reverse phase column, and the mobile phase composition of $0.01 \mathrm{~N} \mathrm{KH}_{2} \mathrm{PO}_{4}$ buffer $(\mathrm{pH} 3.5$ ) and acetonitrile in the ratio of 55:45 was pumped through a column at a flow rate of $1 \mathrm{~mL} / \mathrm{min}$. Repeatability of the method was determined in the form of \% RSD, and findings were 0.3 and 0.6 for ECRB and BMTB, respectively. LOD, LOQ values obtained from regression equations of ECRB and BMTB were 0.51, $1.55 \mathrm{mg} / \mathrm{mL}$ and $1.47,4.44 \mathrm{mg} / \mathrm{mL}$, respectively. Two analytes were subjected to acid, peroxide, photolytic, alkali, neutral, and thermal degradation studies, and the results shown that the percentage of degradation was found between 0.76 and $6.88 \%$. Retention times and the total run time of two drugs were decreased, and the developed method was simple and economical. So, the developed method can be adopted in industries as a regular quality control test to quantify ECRB and BMTB.

\section{REFERENCES}

1. Koelblinger P, Thuerigen O, Dummer R. Development of encorafenib for BRAF-mutated advanced melanoma. Current Opinion in Oncology. 2018;30(2):125-133.

2. Burotto M, Chiou VL, Lee JM, Kohn EC. The MAPK pathway across different malignancies: a new perspective. Cancer. 2014;120(22):3446-56.

3. FDA approves encorafenib and binimetinib in combination for unresectable or metastatic melanoma with BRAF mutations. U.S. Food and Drug Administration (FDA) (Press release). 27 June 2018. Archived from the original on 18 December 2019. Retrieved 28 June 2018.

4. Drug Trial Snapshot: Braftovi. U.S. Food and Drug Administration(FDA). 16 July 2018. Archived from the original on 19 December 2019. Retrieved 18 December 2019.

5. Li Z, Jiang K, Zhu X, Lin G, Song F, Zhao Y, et al. Encorafenib (LGX818), a potentBRAFinhibitor,inducessenescenceaccompanied byautophagy in BRAFV600E melanoma cells. Cancer Letters. 2016;370 (2): 332-344.

6. Koelblinger P, Dornbierer J, Dummer R. A review of binimetinib for the treatment of mutant cutaneous melanoma. Future Oncology. 2017;13 (20):1755-1766.

7. Wu PK, Park JI. MEK1/2 Inhibitors: molecular Activity and Resistance Mechanisms. Seminars in Oncology. 2015;42 (6): 849-62.

8. Ascierto PA, Schadendorf D, Berking C. MEK162 for patients with advanced melanoma harbouring NRAS or Val600 BRAF mutations: a non-randomised, open-label phase 2 study. The Lancet. Oncology. 2013;14 (3): 249-56.

9. Rousset M, Titier K, Bouchet S, Dutriaux C, Pham-Ledard A, Prey S, Canal-Raffin M, molimard M. An UPLC-MS/MS method for the quantification of BRAF inhibitors (vemurafenib, dabrafenib) and MEK inhibitors (cobimetinib, trametinib, binimetinib) in human plasma. Application to treated melanoma patients. Clin. Chim. Acta. 2017;470: 8-13.

10. Kafiya Suroor, Kudaravalli Sreedevi. RP-HPLC method development and validation for the simultaneous estimation of encorafenib and binimetinib in API and tablet dosage form. International Journal of Science and Research. 2019;8(10):184-190.

11. ICH: Q2 (R1), Validation of analytical procedures: text and methodology;2005.

12.ICH: Q2B. Harmonized Tripartite Guideline, Validation of Analytical Procedure: Methodology, IFPMA, in: Proceedings of the International Conference on Harmonization, Geneva;1996.

13. Guguloth R, Madhukar A, Kannappan N, Ravinder A. Method development and validation of new RP- HPLC method for the determination of sofosbuvir tablet, J. Pharma Res. 2016;5(7): 161-163.

14. Charde M S, Welankiwar A S, Chakole R D. Development of validated RP-HPLC method for the simultaneous estimation of atenolol and chlorthalidone in combine tablet dosage form. International Journal of Advances in Pharmaceutics. 2014;3 (1):1-11.

15. de Mendoza AEH, Imbuluzqueta I, et al. Development and validation of ultra-high performance liquid chromatography-mass spectrometry method for LBH589 in mouse plasma and tissues. J Chromatogr B: Anal Technol Biomed Life Sci.. 2011;879:3490-3466. 
16. Madhavi S, Rani AP. Simultaneous reverse phase ultra-performance liquid chromatography method development and validation for estimation of Grazoprevir and Elbasvir. Asian J Pharm ClinRes.. 2018;11:100.

17. Ngwa G. Forced degradation as an integral part of HPLC stability- indicating method development. Drug delivery technology. 2010 Jun;10(5):56-59.

18. Mule KL. Rapid analytical method for assay determination for prochlorperazine edisylate drug substances by ultra-performance liquid chromatography. Int J Curr Pharm Res. 2017;9(4):118-122.

HOW TO CITE THIS ARTICLE: Raveendranath TV, Saravanakumar RT, Male A. Stability-indicating reversed phase-ultra performance liquid chromatography method development and validation for simultaneous determination of encorafenib and binimetinib in formulation. Int. J. Pharm. Sci. Drug Res. 2020;12(5):488-494. DOI: 10.25004/IJPSDR.2020.120509 